\title{
Moringa oleifera leaf meal as a protein source in lactating goat's diets: Feed intake, digestibility, ruminal fermentation, milk yield and composition, and its fatty acids profile
}

\author{
A.E. Kholif ${ }^{a}$, G.A. Gouda ${ }^{\text {a }}$, T.A. Morsy ${ }^{\text {a }}$, A.Z.M. Salem ${ }^{\text {b,* }}$, S. Lopez ${ }^{c}$, A.M. Kholif $^{\text {a }}$ \\ a Dairy Science Department, National Research Centre, 33 Bohouth St. Dokki, Giza, Egypt \\ ${ }^{\mathrm{b}}$ Facultad de Medicina Veterinaria y Zootecnia, Universidad Autónoma del Estado de México, Mexico \\ c Instituto de Ganadería de Montaña (IGM) CSIC-Universidad de León, Departamento de Producción Animal, Universidad de León, \\ E-24071 León, Spain
}

\section{A R T I C L E I N F O}

\section{Article history:}

Received 6 March 2015

Received in revised form 6 May 2015

Accepted 7 May 2015

Available online 18 May 2015

\section{Keywords:}

Dairy goat

Digestibility

Fatty acids

Milk

Moringa oleifera

Rumen fermentation

\begin{abstract}
A B S T R A C T
Sixteen lactating Anglo-Nubian goats ( $36.2 \pm 0.7 \mathrm{~kg} \mathrm{BW}$ ) were used in quadruplicated $4 \times 4$ Latin square design to evaluate the inclusion of Moringa oleifera leaf meal (MLM) in their diets. M. oleifera leaf meal inclusion rates were 0 (M0 or control, no MLM, only sesame meal), 10 (M10), 15 (M15) and 20\% (M20), replacing sesame meal by 0 (control), 50, 75 and $100 \%$, respectively. Goats fed on M15 and M20 diets showed increased feed intake of most nutrients $(P<0.05)$. Moreover, dry matter, organic matter, and fibre digestibilities were increased $(P<0.05)$ with M15 diet. Goats fed on M15 diet showed increased $(P<0.05)$ ruminal $\mathrm{pH}$, volatile fatty acids and propionate concentrations compared to the control diet. Blood glutamic-pyruvic transaminase concentration was increased $(P<0.05)$, and urea- $\mathrm{N}$ and cholesterol concentrations were decreased $(P<0.05)$ in goats fed MLM diets. Milk yield and energy corrected milk were increased $(P<0.01)$ in goats fed MLM, and the greatest increase was observed in the group fed the M15 diet. Feeding MLM also affected milk composition increasing $(P<0.05)$ total solids and lactose contents. Milk components outputs were increased in goats fed MLM compared to control $(P<0.01)$. The relative percentage of saturated fatty acids was decreased $(P<0.05)$, and those of unsaturated (mono- or poly-) fatty acids and of conjugated linoleic acid were increased $(P<0.05)$ in the milk of goats fed M15 and M20 diets. M. oleifera can replace sesame meal as a protein source in diets for lactating goats. The inclusion of MLM increased feed intake, enhanced nutrient digestibility and ruminal fermentation, increased milk yield and modified milk fatty acid profile positively. An inclusion rate of $15 \%$ MLM (replacing $75 \%$ of sesame meal) in the diet was the most suitable level for lactating goats under the current experiment conditions.
\end{abstract}

(c) 2015 Elsevier B.V. All rights reserved.

\footnotetext{
* Corresponding author. Tel.: +20 52172229655 42; fax: +20 5217221806194 .

E-mail address: asalem70@yahoo.com (A.Z.M. Salem).
} 


\section{Introduction}

The availability and price of concentrates, in particular of protein sources, are a serious problem for animal producers, especially for small farms stakeholders. Consequently, there is a need for alternative ingredients with high protein content and balanced amino acids profile, and with a suitable cost. Plants leaf meal, forage trees, saltbush and shrubs are good and cheap sources of protein (MendietaAraica et al., 2011a; Alsersy et al., 2015; Salem et al., 2006, 2015).

One of these potential tree forages is Moringa oleifera Lam (syns. Moringa pterygosperm, family Moringaceae), which grows throughout the tropics (Debela and Tolera, 2013). M. oleifera is an indigenous native tree from the Himalaya (Duke, 2001) but, at present, it is widely distributed almost worldwide (Soliva et al., 2005). M. oleifera can be grown in humid, hot, dry tropical and subtropical regions. It is a drought tolerant plant that can grow in all types of soils, except those that are waterlogged (Abdul, 2007), and can tolerate dry seasons lasting up to 6 months (Mendieta-Araica et al., 2013). The yield per ha varies widely depending on season, variety, fertilization, irrigation regimen, accession and ecological zone (Palada et al., 2007). Reported yields range from 43 to 115 tonnes of biomass ha ${ }^{-1}$ year $^{-1}$ (Foidl et al., 2001; Safwat et al., 2014), with about 4.2-24 tonnes ha ${ }^{-1}$ year $^{-1}$ of dry matter (DM) (Reyes-Sánchez et al., 2006; Nouman et al., 2014). Most of the production is located in India with 1.1-1.3 million tonnes year ${ }^{-1}$ harvested from 38,000 ha (Patel et al., 2010). No information is available about the global and Egyptian production of M. oleifera leaves or seeds. In Egypt, M. oleifera is grown for human consumption; however, the low price of foliage encourages its use as animal feed. The price per $\mathrm{kg}$ DM varies considerably from 1 to 1.5 US\$ for dried leaves up to $20-24$ US\$ for seeds. The price of branches with leaves and soft twigs as animal feed can be around $0.25-0.5$ US\$ per kg DM. M. oleifera leaf meal (MLM) contains from 179 to $268 \mathrm{~g}$ crude protein (CP)/ $\mathrm{kg}$ DM (Sultana et al., 2015), with about $47 \%$ of bypass protein (Becker, 1995) and with adequate amino acid profile (Sánchez-Machado et al., 2010). The chemical composition of MLM can vary considerably depending on the proportions of small branches, twigs and leaf (MendietaAraica et al., 2011a), stage of maturity, time of sampling and Moringa species (Debela and Tolera, 2013), and agroecological zone where trees are growing (Sultana et al., 2015).

Experiments including Moringa fresh foliage in the diets of goats (Sultana et al., 2015), sheep (Fadiyimu et al., 2010) and cows (Mendieta-Araica et al., 2011b) have reported improved feed utilization and animal productive performance. Mendieta-Araica et al. (2011b) fed dairy cows fresh or ensiled Moringa foliage versus Elephant grass and reported unaffected live weights and milk yield and composition with increasing intake of fresh Moringa, in spite of higher $\mathrm{CP}$ and fibre digestibilities for ensiled $M$. oleifera. Moreover, Fadiyimu et al. (2010) included M. oleifera at different levels in diets for sheep, and reported decreased intake with increasing $M$. oleifera in the diet, but with increased nutrients digestibility.
Little information about M. oleifera as a protein source in the diet of ruminants is available. Therefore, the aim of this study was to evaluate the effects of replacing partially or completely a conventional protein source (sesame meal) with MLM in diets for lactating Anglo-Nubian goats on feed intake, digestibility, blood chemistry, and milk yield and composition.

\section{Materials and methods}

Goats were cared and handled in accordance with the Guide for the Care and Use of Agricultural Animals in Agricultural Research and Teaching (FASS, 1999). The trial was conducted at a family owned commercial dairy farm near Behera governorate (Egypt) and at the Laboratory of Dairy Animal Production, National Research Centre (Egypt). The farm is located at latitude $31^{\circ} 04^{\prime} 02.4^{\prime \prime} \mathrm{N}$ and longitude $30^{\circ} 31^{\prime} 42.19^{\prime \prime} \mathrm{E}$. The local climate is temperate-tropic humid with summer rains and with an annual average rainfall of $22 \mathrm{~mm}$ and mean annual temperature between 14 and $28^{\circ} \mathrm{C}$.

\subsection{Moringa oleifera planting and preparation}

Viable, clean and disease free $M$. oleifera seeds were obtained from The Egyptian Association of Moringa (National Research Centre, Egypt), and planted in density 100,000-150,000 seeds per ha. Before sowing, seeds were soaked in water for $24 \mathrm{~h}$ then kept in dark for $24 \mathrm{~h}$ for scarification and better germination. The land was irrigated biweekly with $1800 \mathrm{~m}^{3}$ water ha $\mathrm{a}^{-1}$ month $^{-1}$. Before starting the experiment, a uniformity cut was carried out 65 days after seeding, when plants reached a height of $65-70 \mathrm{~cm}$ (5-7 mm cutting height). Usually, M. oleifera is then cut after 40 days of regrowth resulting in 9 harvests per year and yielding $70-80$ tonnes of fresh biomass ha ${ }^{-1}$ year $^{-1}\left(\sim 23\right.$ tonnes DM ha ${ }^{-1}$ year $\left.^{-1}\right)$. For this particular experiment, Moringa biomass (composed of leaves and thin twigs, branches and stems) was harvested in a different way following a cut-and-carry approach so that the amount of Moringa biomass required to feed the goats was collected daily from the field every morning, mixed with the diet and immediately offered to the goats. The material collected was always from $40( \pm 5)$ days aftermaths. Additionally, Moringa material was sampled daily, composited weekly and dried at $60^{\circ} \mathrm{C}$ in a forced-air oven for $48 \mathrm{~h}$ and stored for later chemical analysis.

\subsection{Goats, feeding and experimental design}

Sixteen lactating Anglo-Nubian goats (36.2 $\pm 0.7 \mathrm{~kg}$ of BW) were randomly assigned to four experimental groups. The experimental design was a quadruplicated $4 \times 4$ Latin square, with four treatments, four periods and four goats per treatment within each period (resulting in 16 replicates per treatment for the whole experiment). The four experimental treatments were randomly assigned to the four groups in the first period. The goats were housed individually in tie stalls with free access to water and fed on the experimental diets to meet their nutrient requirements according to NRC (2007) recommendations plus a $10 \%$ margin.

The basal diet fed to the goats contained $400 \mathrm{~g}$ of Egyptian berseem clover (Trifolium alexandrinum), $300 \mathrm{~g}$ of crushed yellow corn, $80 \mathrm{~g}$ of wheat bran and $20 \mathrm{~g}$ of minerals and vitamins per $\mathrm{kg}$ total mixed ration (DM basis). In the control diet (M0), the protein source was sesame meal included at $200 \mathrm{~g} / \mathrm{kg}$ DM. In the other experimental diets, $50 \%, 75 \%$ or $100 \%$ of the sesame meal was replaced with MLM, by including 100 (M 10), 150 (M15) or 200 (M20) g of MLM per kg diet (on DM basis). Diets were fed to each goat individually at 08:00 and 16:00 $\mathrm{h}$ in two equal portions. Feed samples of berseem clover, concentrates mixture and MLM were taken daily, composited weekly and dried at $60^{\circ} \mathrm{C}$ in a forced-air oven for $48 \mathrm{~h}$ and stored for later chemical analysis. The ingredient and nutrient contents of the four diets are in Table 1.

Each experimental period lasted 22 days; 15 days of adaptation to the new diet, and 7 days for measurements (feed intake, milk yield) and sample collection (sampling of feed and orts, faeces, ruminal fluid, blood, milk). Feed intake (recorded daily by weighing the offered diets and refusals from the previous day) and milk yield were measured daily. Faecal grab samples were collected twice daily at 07:00 and 15:00 h, dried at $60{ }^{\circ} \mathrm{C}$ in a forced-air oven for $48 \mathrm{~h}$ and pooled by goat within period. Acid insoluble ash was used as an internal indigestibility marker, and coefficients of digestion calculated according to Ferret et al. (1999). 
Table 1

Ingredients and chemical composition of feeding stuffs and total mixed rations fed to the lactating Anglo-Nubian goats.

\begin{tabular}{|c|c|c|c|c|c|c|c|c|c|}
\hline & \multicolumn{5}{|c|}{ Ingredients } & \multicolumn{4}{|l|}{ Diets $^{\mathrm{a}}$} \\
\hline & $\begin{array}{l}\text { Berseem } \\
\text { hay }\end{array}$ & $\begin{array}{l}\text { Moringa } \\
\text { oleifera }\end{array}$ & $\begin{array}{l}\text { Crushed } \\
\text { yellow } \\
\text { corn }\end{array}$ & $\begin{array}{l}\text { Sesame } \\
\text { meal }\end{array}$ & $\begin{array}{l}\text { Wheat } \\
\text { bran }\end{array}$ & M0 & M10 & M15 & M20 \\
\hline \multicolumn{10}{|l|}{ Ingredients ( $\mathrm{g} / \mathrm{kg}$ DM basis) } \\
\hline Berseem hay & & & & & & 400 & 400 & 400 & 400 \\
\hline Moringa oleifera & & & & & & 0 & 100 & 150 & 200 \\
\hline Crushed yellow corn & & & & & & 300 & 300 & 300 & 300 \\
\hline Sesame meal & & & & & & 200 & 100 & 50 & 0 \\
\hline Wheat bran & & & & & & 80 & 80 & 80 & 80 \\
\hline Calcium carbonate & & & & & & 10 & 10 & 10 & 10 \\
\hline Salt & & & & & & 5 & 5 & 5 & 5 \\
\hline Minerals and vitamins mixture ${ }^{\mathrm{b}}$ & & & & & & 5 & 5 & 5 & 5 \\
\hline \multicolumn{10}{|l|}{ Chemical composition (g/kg DM basis) } \\
\hline Dry matter ( $\mathrm{g} / \mathrm{kg}$ wet material) & 875.0 & 320.2 & 866.0 & 898.1 & 871.4 & 859.2 & 801.4 & 772.5 & 743.6 \\
\hline Organic matter & 857.9 & 889.0 & 890.3 & 869.3 & 852.2 & 852.3 & 854.3 & 855.2 & 856.2 \\
\hline Crude protein & 143.7 & 241.2 & 90.8 & 259.0 & 129.7 & 146.9 & 145.1 & 144.2 & 143.3 \\
\hline Ether extract & 49.9 & 47.3 & 45.2 & 119.9 & 56.2 & 62.0 & 54.7 & 51.1 & 47.5 \\
\hline Non-structural carbohydrates & 213.1 & 263.9 & 540.0 & 211.3 & 204.4 & 305.9 & 311.1 & 313.7 & 316.4 \\
\hline Neutral detergent fibre & 451.2 & 336.6 & 214.3 & 279.1 & 461.9 & 337.5 & 343.3 & 346.2 & 349.0 \\
\hline Acid detergent fibre & 347.6 & 275.0 & 88.8 & 151.3 & 130.6 & 206.4 & 218.8 & 224.9 & 231.1 \\
\hline Acid detergent lignin & 51.7 & 81.6 & 10.4 & 41.5 & 38.0 & 35.1 & 39.2 & 41.2 & 43.2 \\
\hline Cellulose & 295.9 & 193.4 & 78.4 & 109.8 & 92.6 & 171.3 & 179.6 & 183.8 & 187.9 \\
\hline Hemicellulose & 103.6 & 61.6 & 125.5 & 127.8 & 331.3 & 131.2 & 124.5 & 121.3 & 117.9 \\
\hline Total phenolic & & 45.15 & & 14.33 & & & & & \\
\hline Tannins & & 25.63 & & 5.24 & & & & & \\
\hline
\end{tabular}

a Moringa oleifera added at 0\%(M0), 10\% (M10), 15\% (M15) and 20\% (M20), replacing 0\%, 50\%, $75 \%$ and 100\% of sesame meal, respectively.

b Contained: Ca $(141 \mathrm{~g} / \mathrm{kg}), \mathrm{P}(87 \mathrm{~g} / \mathrm{kg}), \mathrm{Mg}(45 \mathrm{~g} / \mathrm{kg}), \mathrm{S}(14 \mathrm{~g} / \mathrm{kg}), \mathrm{Na}(120 \mathrm{~g} / \mathrm{kg}), \mathrm{K}(6 \mathrm{~g} / \mathrm{kg}), \mathrm{Fe}(944 \mathrm{mg} / \mathrm{kg}), \mathrm{Zn}(1613 \mathrm{mg} / \mathrm{kg}), \mathrm{Cu}(484 \mathrm{mg} / \mathrm{kg}), \mathrm{Mn}$ (1748 mg/kg), I (58 mg/kg), Co (51 mg/kg), Se (13 mg/kg), vitamin A (248,000 U/kg), vitamin D3 (74,000 UI/kg), vitamin E (1656 IU/kg).

Dried feed, feed orts and faecal samples were ground through a $1 \mathrm{~mm}$ screen using a Wiley mill (Arthur H. Thomas, Philadelphia, PA, USA), and analyzed for DM (\#930.15), ash (\#942.05), N (\#954.01), and ether extract (EE; \#920.39), according to AOAC (1995) official methods. Neutral detergent fibre (NDF), acid detergent fibre (ADF) and acid detergent lignin were analyzed according to Van Soest et al. (1991). Nonstructural carbohydrates (NSC), cellulose, hemicelluloses and organic matter (OM) were calculated. Tannin concentrations in MLM and sesame meals were determined according to Makkar (2003), and total phenolic content were determined chromatographically according to Meier et al. (1988)

\subsection{Sampling and analysis of rumen fluid}

On the last day of each experimental period, ruminal contents were sampled at 0,3 , and $6 \mathrm{~h}$ post morning feeding to determine the $\mathrm{pH}$ and concentration of fermentation end-products. Rumen contents $(\sim 100 \mathrm{~mL})$ were collected once at each sampling time from the ventral sac by using a stomach tube, and then composite samples taken from each goat were strained through 4 layers of cheesecloth. The $\mathrm{pH}$ of ruminal fluid was measured immediately using a pH metre (HI98127 $\mathrm{pHep}^{\circledR} 4 \mathrm{pH} /$ Temperature Tester, Hanna ${ }^{\circledR}$ instrument, Italy).

A subsample of $5 \mathrm{~mL}$ was preserved in $5 \mathrm{~mL}$ of $0.2 \mathrm{M} \mathrm{HCl}$ for ammonia$\mathrm{N}$ analysis and $0.8 \mathrm{~mL}$ of rumen liquor was mixed with $0.2 \mathrm{~mL}$ of a solution containing $250 \mathrm{~g}$ of metaphosphoric acid/L for total volatile fatty acids (tVFA) analysis. Samples collected at $3 \mathrm{~h}$ post-feeding were analyzed for the individual VFA. All samples were stored at $-20^{\circ} \mathrm{C}$ until laboratory analyses. The concentration of ruminal ammonia- $\mathrm{N}$ was determined according to AOAC (1995). Total VFA concentration in samples was determined by titration, after steam distillation of a $4 \mathrm{~mL}$ sample, by the method of Annison (1954). The percentages of the individual VFA were measured by gas-liquid chromatography (Varian 3700; Varian Specialties Ltd, Brockville, Ontario, Canada).

\subsection{Sampling and analysis of blood serum}

On the last day of each experimental period, blood samples $(10 \mathrm{~mL})$ were taken $4 \mathrm{~h}$ after feeding from the jugular vein of each goat into a clean dry tube, without anticoagulants. Blood samples were centrifuged at $4000 \times \mathrm{g}$ at $4{ }^{\circ} \mathrm{C}$ for $20 \mathrm{~min}$. Serum was separated into $2 \mathrm{~mL}$ clean dried Eppendorf tubes and frozen at $-20^{\circ} \mathrm{C}$ until analysis.

Blood serum samples were analyzed for concentrations of total protein, albumin, urea-N, glutamate-oxaloacetate transaminase (GOT), glutamate-pyruvate transaminase (GPT), glucose, creatinine, cholesterol and triglycerides using specific kits (Stanbio Laboratory, Boerne, Texas, USA) following manufacturer instructions. Globulin concentration was calculated.

\subsection{Milk sampling, milk composition and fatty acids analysis}

During the last 7 days of each experimental period, goats were milked by hand twice daily at 09:00 and $21: 00 \mathrm{~h}$, and samples $(10 \%$ of recorded milk yield) were collected at each milking. A mixed sample of morning and evening milkings was taken daily. Milk samples were analyzed for total solids, fat, protein, and lactose using infrared spectrophotometry (Foss 120 Milko-Scan, Foss Electric, Hillerød, Denmark). The ash content of milk was determined after heating a milk sample in a muffle furnace at $550{ }^{\circ} \mathrm{C}$ for $8 \mathrm{~h}$. Fatty acids in milk were determined as described previously in Kholif et al. (2014) using methyl esters prepared by base-catalysed methanolysis of the glycerides ( $\mathrm{KOH}$ in methanol) according to International Standards (ISO-IDF, 2002) on a Perkin-Elmer chromatograph (model 8420, Beaconsfield, Perkin Elmer, Beaconsfield, UK) equipped with a flame ionization detector.

Average yields $(\mathrm{g} / \mathrm{d})$ of each milk component were calculated for each individual goat by multiplying milk yield by the component content $(\mathrm{g} / \mathrm{kg})$ of milk. The gross energy content in milk was calculated according to Tyrell and Reid (1965) as:

Milk energy content $(\mathrm{MJ} / \mathrm{kg})=4.184 \times 2.204 \times[41.63 \times$ fat $(\mathrm{g} / \mathrm{kg})$

$$
\begin{aligned}
& +24.13 \times \text { protein }(\mathrm{g} / \mathrm{kg})+21.60 \\
& \times \text { lactose }(\mathrm{g} / \mathrm{kg})-117.2 \mathrm{]} / 10000 .
\end{aligned}
$$

The milk energy output $(\mathrm{MJ} / \mathrm{d})$ was then calculated as milk energy $(\mathrm{MJ} / \mathrm{kg}) \times$ milk yield $(\mathrm{kg} / \mathrm{d})$ 
Energy corrected milk (ECM) was calculated according to Sjaunja et al. (1991) as:

ECM $(\mathrm{kg} / \mathrm{d})=$ milk yield $(\mathrm{kg} /$ day $) \times[38.3 \times$ fat $(\mathrm{g} / \mathrm{kg})+24.2$

$$
\times \text { protein }(\mathrm{g} / \mathrm{kg})+16.54 \times \text { lactose }(\mathrm{g} / \mathrm{kg})+20.7 \mathrm{]} / 3140 \text {. }
$$

\subsection{Statistical analyses}

Data on nutrient intake, digestibility, blood chemistry parameters and milk yield and composition (including fatty acids profile) were analyzed using a quadruplicated $4 \times 4$ Latin square design, with four periods and four experimental diets (M0, M10, M15 and M20). Four lactating goats were used within each period and treatment. Each goat was an experimental unit, thus resulting in 16 replicates per treatment ( 4 per period). The statistical model included a random effect of goat $\left(G_{k}\right)$ with period $\left(P_{i}\right)$ and $\operatorname{diet}\left(D_{j}\right)$ as fixed effects: $y_{i j k}=\mu+P_{i}+D_{j}+G_{k}+E_{i j k}$, where $y_{i j k}$ is each individual observation for a given variable, $\mu$ is the overall mean and $E_{i j k}$ is the residual random term. Statistical analyses were performed using PROC MIXED of SAS (SAS Inst. Inc. Cary, NC, 2004). In the case of ruminal fermentation variables measured at different times ( 0,3 and $6 \mathrm{~h}$ post-feeding), a model with repeated measures in time on the same experimental unit was used. The interactions time $\times$ diet were never significant, and only diet effects within each sampling time will be reported. The Tukey test was used for the multiple comparisons of means, and polynomial (linear and quadratic) contrasts were used to examine the dose responses to increasing levels of MLM in the diet. Significance was declared at a level of $P<0.05$ and trend of $P \leq 0.10$.

\section{Results}

\subsection{Feed intake and nutrient digestibility}

Feed intake by goats was significantly $(P<0.0001)$ increased with diets containing MLM. Goats fed on MLM diets consumed more (significant linear and quadratic trends, $P<0.05$ ) feed nutrients (except for EE and hemicelluloses) than goats fed the control diet. The goats fed the M15 diet showed the greatest feed and nutrient intakes. Moreover, the digestibility of DM $(P<0.0001)$, OM $(P<0.0001), \operatorname{NDF}(P=0.0157), \operatorname{ADF}(P<0.0001)$ and cellulose $(P<0.0001)$ was increased when goats were fed MLM diets. However, feeding goats on MLM decreased $(P<0.0001) C P$ digestibility. No differences $(P>0.05)$ were observed for EE, NSC and hemicelluloses digestibilities (Table 2).

Total digestible nutrients (quadratic, $P=0.0049$ ), digestible CP (quadratic, $P<0.0001$ ), digestible energy (quadratic, $P=0.0054$ ), metabolizable energy (quadratic, $P=0.0054$ ) and net energy of lactation (quadratic, $P=0.0049$ ) were decreased in M20 compared to M0 diet (Table 2).

\subsection{Ruminal fermentation kinetics and blood parameters}

For ruminal $\mathrm{pH}$, goats fed on M10 and M20 diets had increased $(P<0.05)$ ruminal $\mathrm{pH}$ at the time of feeding, with no differences $(P>0.05)$ after 3 and $6 \mathrm{~h}$. Goats fed the M15 diet showed increased $(P<0.05)$ tVFA at all sampling times, compared to the goats of the control group. Ruminal ammonia-N concentrations determined at 3 and $6 \mathrm{~h}$ after feeding were decreased $(P<0.05)$ in goats fed MLM diets compared to the control diet (Table 3 ).

No significant diet effects $(P>0.05)$ were observed on ruminal acetic (C2) and butyric (C4) acid concentrations at
$3 \mathrm{~h}$ after feeding. However, the concentration of propionic acid (C3) was increased in the rumen of goats fed the M15 $\operatorname{diet}(P=0.0209)$ compared to M0 diet. Consequently, the $\mathrm{C} 2 / \mathrm{C} 3$ ration was decreased $(P=0.0091)$ in the rumen of goats fed MLM diets (Table 3$)$.

Feeding MLM diets to goats had no significant effects $(P>0.05)$ on serum total proteins, albumin, globulin, glucose, creatinine, GOT and triglycerides concentrations (data not shown). However, the serum concentration of GPT was increased (quadratic, $P=0.0141$ ) in goats fed the M20 diet compared to the control diet. Decreased urea$\mathrm{N}$ (linear, $P=0.0339$; quadratic, $P<0.0001$ ) and cholesterol (linear, $P=0.0009$; quadratic, $P<0.0001$ ) concentrations were observed in the serum of goats fed MLM diets (Table 3).

\subsection{Milk yield and composition}

Milk yield (linear, $P=0.0001$; quadratic, $P=0.0352$ ), energy corrected milk yield (linear, $P<0.0001$; quadratic, $P=0.0299$ ), milk energy output (linear, $P<0.0001$; quadratic, $P=0.0259$ ), and milk constituent (fat, protein, lactose) outputs $(P<0.001)$ were significantly increased when goats were fed MLM diets compared to the control diet. The greatest milk yields were observed in goats fed the M15 diet. Total solids (linear, $P=0.0402$ ) and lactose (linear, $P=0.001$ ) milk contents were increased in goats fed the M15 diet compared to those fed the control diet (Table 4).

The milk fatty acid profile was significantly modified when goats were fed MLM diets (Table 5). The relative percentages of $\mathrm{C} 14: 1 \quad(P=0.0017), \mathrm{C} 18: 1^{\text {n9T }}(P=0.0017)$, C18: $1^{\text {n9C }}(P=0.0037), C 18: 2^{\text {trans-10, cis-12 }}(P=0.0005)$ and C18: $2^{\text {cis-9, trans-11 }}(P=0.0032)$ were increased, and the concentration of $\mathrm{C} 16: 0(P=0.0011)$ was decreased, in the milk of goats fed M15 and M20 diets. Consequently, the relative percentages of total unsaturated (TUFA; $P=0.001$ ), monounsaturated (MUFA; $P=0.0014$ ), and polyunsaturated fatty acids (PUFA; $P=0.0051$ ), and of total conjugated linoleic acid (CLA; $P=0.0004)$, and the TUFA/total saturated fatty acids ratio, (TSFA; $P=0.0014$ ) were increased in the milk of goats fed the M15 and M20 diets compared to the control diet. On the contrary, the percentage of TSFA was decreased $(P=0.001)$ in the milk of goats fed MLM diets (Table 5).

\section{Discussion}

In the current study, MLM contained about 24\% CP ( $\sim 47 \%$ of bypass protein; Becker, 1995). Although this content is less than in sesame meal (26\%), soybean meal ( 40-44\% CP), cottonseed meal ( 40\% CP) and sunflower seed cake $(\sim 35 \% \mathrm{CP})$, which are mostly used as protein concentrates in ruminant nutrition, the MLM may be considered as a good potential source of supplementary protein for ruminants (Debela and Tolera, 2013). The amino acid supply from this protein concentrate may be of particular nutritional significance as it may cover goat's protein needs and boost the immune system against diseases (Brisibe et al., 2009). In general, dairy goats require about $16 \%$ CP (NRC, 2007), and thus MLM may be included as 
Table 2

Feed intake, nutrients digestibility and nutritive value of diets with different levels of Moringa oleifera replacing sesame meal as a protein source and fed to lactating Anglo-Nubian goats $(n=16)$.

\begin{tabular}{|c|c|c|c|c|c|c|c|c|}
\hline & \multicolumn{4}{|l|}{ Diets $^{*}$} & \multirow[t]{2}{*}{ SEM } & \multicolumn{3}{|l|}{$P$ value } \\
\hline & M0 & M10 & M15 & M20 & & Control vs. Moringa & Linear & Quadratic \\
\hline \multicolumn{9}{|l|}{ Intake (g/d) } \\
\hline Dry matter & $730.8^{c}$ & $792.8^{\mathrm{b}}$ & $848.7^{\mathrm{a}}$ & $801.1^{\mathrm{b}}$ & 8.39 & $<0.0001$ & $<0.0001$ & 0.0004 \\
\hline Organic matter & $622.8^{c}$ & $677.3^{\mathrm{b}}$ & $725.8^{\mathrm{a}}$ & $685.9^{\mathrm{b}}$ & 7.18 & $<0.0001$ & $<0.0001$ & 0.0002 \\
\hline Crude protein & $107.3^{c}$ & $115.0^{\mathrm{b}}$ & $122.4^{\mathrm{a}}$ & $114.8^{\mathrm{b}}$ & 1.21 & $<0.0001$ & $<0.0001$ & 0.0186 \\
\hline Ether extract & $45.3^{\mathrm{a}}$ & $43.4^{\mathrm{b}}$ & $43.4^{\mathrm{b}}$ & $38.0^{c}$ & 0.42 & $<0.0001$ & 0.0028 & $<0.0001$ \\
\hline Non-structural carbohydrates & $223.5^{c}$ & $246.6^{\mathrm{b}}$ & $266.2^{\mathrm{a}}$ & $253.5^{\mathrm{b}}$ & 2.64 & $<0.0001$ & $<0.0001$ & $<0.0001$ \\
\hline Neutral detergent fibre & $246.6^{c}$ & $272.2^{\mathrm{b}}$ & $293.8^{\mathrm{a}}$ & $279.6^{\mathrm{b}}$ & 2.91 & $<0.0001$ & $<0.0001$ & $<0.0001$ \\
\hline Acid detergent fibre & $150.8^{c}$ & $173.5^{\mathrm{b}}$ & $190.9^{\mathrm{a}}$ & $185.1^{\mathrm{a}}$ & 1.91 & $<0.0001$ & $<0.0001$ & $<0.0001$ \\
\hline Cellulose & $125.5^{\mathrm{c}}$ & $142.4^{\mathrm{b}}$ & $156.0^{\mathrm{a}}$ & $150.6^{\mathrm{a}}$ & 1.54 & $<0.0001$ & $<0.0001$ & $<0.0001$ \\
\hline Hemicelluloses & $95.5^{\mathrm{bc}}$ & $98.7^{\mathrm{b}}$ & $102.9^{\mathrm{a}}$ & $94.4^{\mathrm{c}}$ & 1.04 & $<0.0001$ & 0.0367 & 0.0409 \\
\hline \multicolumn{9}{|l|}{ Digestibility (g absorbed/kg ingested) } \\
\hline Dry matter & $574.5^{c}$ & $590.9^{\mathrm{bc}}$ & $644.1^{\mathrm{a}}$ & $612.5^{\mathrm{b}}$ & 7.11 & $<0.0001$ & 0.1103 & 0.0014 \\
\hline Organic matter & $609.5^{\mathrm{b}}$ & $627.6^{\mathrm{ab}}$ & $645.0^{\mathrm{a}}$ & $611.6^{\mathrm{b}}$ & 4.87 & $<0.0001$ & 0.0117 & 0.2516 \\
\hline Crude protein & $625.2^{\mathrm{a}}$ & $620.5^{\mathrm{ab}}$ & $605.9^{\mathrm{b}}$ & $584.9^{c}$ & 4.76 & $<0.0001$ & 0.4873 & $<0.0001$ \\
\hline Ether extract & 602.4 & 597.4 & 591.6 & 593.4 & 6.51 & 0.6564 & 0.5934 & 0.4174 \\
\hline Non-structural carbohydrates & 566.0 & 560.7 & 560.2 & 558.9 & 6.10 & 0.7718 & 0.4626 & 0.4871 \\
\hline Neutral detergent fibre & $572.9^{\mathrm{b}}$ & $586.5^{\mathrm{ab}}$ & $608.5^{\mathrm{a}}$ & $590.0^{\mathrm{ab}}$ & 7.46 & 0.0157 & 0.2069 & 0.2663 \\
\hline Acid detergent fibre & $566.1^{\mathrm{b}}$ & $580.8^{\mathrm{b}}$ & $607.6^{\mathrm{a}}$ & $584.3^{\mathrm{b}}$ & 5.52 & $<0.0001$ & 0.0660 & 0.1169 \\
\hline Cellulose & $602.5^{\mathrm{b}}$ & $611.2^{\mathrm{b}}$ & $645.5^{\mathrm{a}}$ & $620.3^{\mathrm{b}}$ & 5.73 & $<0.0001$ & 0.2900 & 0.0610 \\
\hline Hemicelluloses & 578.7 & 571.6 & 582.9 & 569.3 & 8.20 & 0.6238 & 0.5427 & 0.5606 \\
\hline \multicolumn{9}{|l|}{ Digestible nutrients and energy value $^{\dagger}$} \\
\hline Total digestible nutrients (g/kg DM) & $569.0^{\mathrm{a}}$ & $563.9^{\mathrm{ab}}$ & $562.8^{\mathrm{ab}}$ & $555.1^{\mathrm{b}}$ & 31.30 & 0.0262 & 0.2484 & 0.0049 \\
\hline Digestible crude protein (g/kg DM) & $91.8^{\mathrm{a}}$ & $90.0^{\mathrm{a}}$ & $87.4^{\mathrm{b}}$ & $83.8^{\mathrm{c}}$ & 0.69 & $<0.0001$ & 0.0706 & $<0.0001$ \\
\hline Digestible energy (MJ/kg DM) & $10.5^{\mathrm{a}}$ & $10.4^{\mathrm{ab}}$ & $10.4^{\mathrm{ab}}$ & $10.3^{\mathrm{b}}$ & 0.059 & 0.0266 & 0.2194 & 0.0054 \\
\hline Metabolizable energy (MJ/kg DM) & $10.6^{\mathrm{a}}$ & $10.5^{\mathrm{ab}}$ & $10.5^{\mathrm{ab}}$ & $10.4^{\mathrm{b}}$ & 0.059 & 0.0295 & 0.2652 & 0.0054 \\
\hline Net energy of lactation (MJ/kg DM) & $5.4^{\mathrm{a}}$ & $5.3^{\mathrm{ab}}$ & $5.3^{\mathrm{ab}}$ & $5.2^{\mathrm{b}}$ & 0.033 & 0.0258 & 0.2416 & 0.0049 \\
\hline
\end{tabular}

${ }^{*}$ Moringa oleifera added at 0\% (M0), 10\% (M10), 15\% (M15) and 20\% (M20), replacing 0\%, 50\%, 75\% and 100\% of sesame meal, respectively.

$\dagger$ Calculated according to (NRC, 2001).

${ }^{a b c}$ Means in the same row with different superscripts significantly differ $(P<0.05)$.

$\mathrm{SEM}=$ Standard error of the mean.

a protein supplement to match such requirements (Moyo et al., 2010).

\subsection{Feed intake and nutrient digestibility}

Partial or total replacement of sesame meal with MLM increased feed intake and, by extension, the ingestion of most nutrients and nutritional fractions, suggesting that diets containing MLM may be more palatable than the diet containing sesame meal alone. The low degradability of MLM protein in the rumen may also affect intake, as an increased provision of undegradable protein can increase feed intake (M'hamed et al., 2001; Kholif et al., 2014). This hypothesis may be supported by the gradual increased intake with increasing MLM inclusion in diets. However, goats fed the M20 diet showed slight decreased intake and digestibility compared to those fed the M15 diet. This may be due to tannins and phenolic compound concentrations observed in MLM compared to sesame meal. Tannins in feeds may reduce feed palatability, slow digestion rate, and contribute to develop conditioned aversions (Frutos et al., 2004). The reaction between feed tannins and salivary proteins causes an astringent sensation reducing palatability (Salem et al., 2013).

The improved nutrients digestibility in M15 goats may be related to improved ruminal fermentation. Frutos et al. (2004) and Salem et al. (2006) reported that less than 5\% is the acceptable level of tannins in feeds without negative effects on digestibility. Rumen microorganisms have the ability to tolerate low and moderate concentrations of the secondary metabolites of plants including phenolic compounds (Varel et al., 1991) and tannins (Frutos et al., 2004) without any negative effects on rumen fermentation.

Mendieta-Araica et al. (2011a) replaced soybean meal at $20 \%$ of diet DM with the same amount of MLM and reported unaffected DM, OM, NDF and ADF intakes and digestibility with significant higher CP intake and digestibility for the soybean meal treatment. Sultana et al. (2015) partially and completely replaced the concentrate feed mixture from the diets of Black Bengal goats with MLM and found that partial replacement increased nutrients intake and NDF digestibility compared to the complete replacement and control.

\subsection{Ruminal fermentation kinetics}

Feeding goats on MLM increased ruminal tVFA concentrations. Lu et al. (2008) reported that an optimum dietary fibre level in the diet enhanced cellulolytic activity in the rumen and increased salivation during eating and ruminating. Ruminal pH in goats fed MLM diets (5.99-7.06) were within the range considered acceptable for fibre digestion (Ørskov and Ryle, 1990). Increased tVFA can be interpreted as a result of improved digestion with MLM diets compared to control. 
Table 3

Ruminal fermentation and blood serum parameters in lactating Anglo-Nubian goats $(n=16)$ fed diets with different levels of Moringa oleifera replacing sesame meal as a protein source.

\begin{tabular}{|c|c|c|c|c|c|c|c|c|}
\hline & \multicolumn{4}{|l|}{ Diets $^{*}$} & \multirow[t]{2}{*}{ SEM } & \multicolumn{3}{|l|}{$P$ value } \\
\hline & M0 & M10 & M15 & M20 & & Control vs. Moringa & Linear & Quadratic \\
\hline \multicolumn{9}{|l|}{$\mathrm{pH}$} \\
\hline $\mathrm{Oh}$ & $6.88^{\mathrm{b}}$ & $7.06^{a}$ & $7.02^{\mathrm{ab}}$ & $7.05^{a}$ & 0.041 & 0.0103 & 0.0031 & 0.1063 \\
\hline $3 \mathrm{~h}$ & 5.83 & 6.05 & 6.04 & 5.99 & 0.071 & 0.1253 & 0.0348 & 0.5977 \\
\hline $6 \mathrm{~h}$ & 6.36 & 6.40 & 6.48 & 6.56 & 0.075 & 0.2604 & 0.7251 & 0.0573 \\
\hline \multicolumn{9}{|l|}{ Ammonia-N (g/L) } \\
\hline $\mathrm{Oh}$ & 21.0 & 20.6 & 20.5 & 20.0 & 0.39 & 0.3458 & 0.4766 & 0.0974 \\
\hline $3 \mathrm{~h}$ & $29.7^{\mathrm{a}}$ & $27.5^{\mathrm{b}}$ & $25.7^{c}$ & $24.9^{c}$ & 0.43 & $<0.0001$ & 0.0010 & $<0.0001$ \\
\hline $6 \mathrm{~h}$ & $25.5^{\mathrm{a}}$ & $24.6^{\mathrm{a}}$ & $22.8^{b}$ & $20.0^{c}$ & 0.31 & $<0.0001$ & 0.0424 & $<0.0001$ \\
\hline \multicolumn{9}{|l|}{ Total volatile fatty acids (tVFA; mmol/L) } \\
\hline $0 \mathrm{~h}$ & $6.12^{\mathrm{b}}$ & $6.69^{\mathrm{ab}}$ & $7.11^{\mathrm{a}}$ & $6.88^{\mathrm{a}}$ & 0.179 & 0.0025 & 0.0300 & 0.0354 \\
\hline $3 \mathrm{~h}$ & $11.99^{\mathrm{b}}$ & $12.89^{\mathrm{ab}}$ & $13.51^{\mathrm{a}}$ & $12.74^{\mathrm{ab}}$ & 0.316 & 0.0148 & 0.0509 & 0.4338 \\
\hline $6 \mathrm{~h}$ & $9.72^{\mathrm{b}}$ & $10.08^{a b}$ & $10.95^{a}$ & $10.60^{a b}$ & 0.293 & 0.0258 & 0.3919 & 0.0599 \\
\hline \multicolumn{9}{|l|}{ Individual VFA at $3 \mathrm{~h}$ after feeding } \\
\hline Acetic (C2; mmol/L) & 7.18 & 6.94 & 7.82 & 7.22 & 0.245 & 0.1743 & 0.5180 & 0.5990 \\
\hline Propionic (C3; mmol/L) & $3.33^{\mathrm{b}}$ & $3.58^{\mathrm{ab}}$ & $4.27^{\mathrm{a}}$ & $3.74^{\mathrm{ab}}$ & 0.148 & 0.0209 & 0.2786 & 0.1695 \\
\hline Butyric $(\mathrm{C} 4 ; \mathrm{mmol} / \mathrm{L})$ & 1.798 & 1.790 & 1.678 & 1.795 & 0.199 & 0.9651 & 0.9796 & 0.9961 \\
\hline Other $(\mathrm{mmol} / \mathrm{L})$ & 0.010 & 0.019 & 0.013 & 0.020 & 0.0063 & 0.6128 & 0.3239 & 0.4631 \\
\hline $\mathrm{C} 2 / \mathrm{C} 3$ & $2.15^{\mathrm{a}}$ & $1.94^{\mathrm{b}}$ & $1.83^{\mathrm{b}}$ & $1.93^{\mathrm{b}}$ & 0.042 & 0.0091 & 0.0114 & 0.0715 \\
\hline \multicolumn{9}{|l|}{ Blood serum parameters } \\
\hline Urea-N (mg/dL) & $44.40^{\mathrm{a}}$ & $40.78^{\mathrm{ab}}$ & $38.25^{\mathrm{bc}}$ & $34.73^{c}$ & 1.170 & $<0.0001$ & 0.0339 & $<0.0001$ \\
\hline Cholesterol (mg/dL) & $128.44^{\mathrm{a}}$ & $121.13^{\mathrm{bc}}$ & $123.50^{\mathrm{ab}}$ & $116.50^{c}$ & 1.450 & $<0.0001$ & 0.0009 & $<0.0001$ \\
\hline Glutamic-pyruvic transaminase (Units/mL) & $18.69^{\mathrm{b}}$ & $20.06^{\mathrm{ab}}$ & $21.44^{\mathrm{ab}}$ & $22.38^{\mathrm{a}}$ & 0.957 & 0.0494 & 0.3153 & 0.0141 \\
\hline
\end{tabular}

${ }^{*}$ Moringa oleifera added at 0\% (M0), 10\% (M10), 15\% (M15) and 20\% (M20), replacing 0\%, 50\%, 75\% and 100\% of sesame meal, respectively. ${ }^{\mathrm{abc}}$ Means in the same row with different superscripts significantly differ $(P<0.05)$.

$\mathrm{SEM}=$ Standard error of the mean.

Ruminal ammonia-N were above the range (0.60-1.59 mM ammonia-N) considered by Satter and Slyter (1974) to be sufficient for microbial protein synthesis. Decreased ruminal ammonia-N concentration with
MLM fed goats compared to control fed goats may be related to the lower protein degradability of Moringa in the rumen. Tannins have an ability to bind to dietary protein, thus protecting it from rumen degradation and increasing

Table 4

Milk yield and composition in lactating Anglo-Nubian goats $(n=16)$ fed diets with different levels of Moringa oleifera replacing sesame meal as a protein source.

\begin{tabular}{|c|c|c|c|c|c|c|c|c|}
\hline & \multicolumn{4}{|l|}{ Diets $^{*}$} & \multirow[t]{2}{*}{ SEM } & \multicolumn{3}{|l|}{$P$ value } \\
\hline & M0 & M10 & M15 & M20 & & Control vs. Moringa & Linear & Quadratic \\
\hline \multicolumn{9}{|l|}{ Milk } \\
\hline Yield (g/d) & $818.6^{\mathrm{b}}$ & $906.9^{a}$ & $943.0^{\mathrm{a}}$ & $901.5^{\mathrm{a}}$ & 14.52 & $<0.0001$ & 0.0001 & 0.0352 \\
\hline Energy corrected milk (g/d) & $777.6^{\mathrm{b}}$ & $872.3^{\mathrm{a}}$ & $917.5^{\mathrm{a}}$ & $865.0^{\mathrm{a}}$ & 14.57 & $<0.0001$ & $<0.0001$ & 0.0299 \\
\hline Milk energy content (MJ/kg) & $3.04^{\mathrm{b}}$ & $3.08^{\mathrm{ab}}$ & $3.12^{\mathrm{a}}$ & $3.07^{\mathrm{ab}}$ & 0.016 & 0.0126 & 0.0898 & 0.4623 \\
\hline Milk energy output (MJ/d) & $2.47^{\mathrm{b}}$ & $2.78^{\mathrm{a}}$ & $2.93^{\mathrm{a}}$ & $2.76^{\mathrm{a}}$ & 0.046 & $<0.0001$ & $<0.0001$ & 0.0259 \\
\hline \multicolumn{9}{|l|}{ Milk composition (g/kg) } \\
\hline Total solids & $122.0^{\mathrm{b}}$ & $124.6^{\mathrm{ab}}$ & $126.3^{\mathrm{a}}$ & $124.6^{\mathrm{ab}}$ & 0.85 & 0.0098 & 0.0402 & 0.2130 \\
\hline Fat & 35.9 & 35.5 & 35.6 & 35.0 & 0.35 & 0.3099 & 0.4041 & 0.0973 \\
\hline Protein & 37.8 & 38.1 & 38.2 & 38.6 & 0.37 & 0.4912 & 0.5900 & 0.1521 \\
\hline Lactose & $41.6^{\mathrm{b}}$ & $44.1^{\mathrm{a}}$ & $45.7^{\mathrm{a}}$ & $44.2^{\mathrm{a}}$ & 0.66 & 0.0007 & 0.0010 & 0.0912 \\
\hline Ash & 6.8 & 7.0 & 6.8 & 6.8 & 0.09 & 0.4130 & 0.1739 & 0.8456 \\
\hline \multicolumn{9}{|l|}{ Milk component yield (g/d) } \\
\hline Total solids & $99.65^{\mathrm{b}}$ & $112.88^{\mathrm{a}}$ & $119.13^{\mathrm{a}}$ & $112.39^{\mathrm{a}}$ & 1.859 & $<0.0001$ & $<0.0001$ & 0.0102 \\
\hline Fat & $29.05^{b}$ & $32.01^{\mathrm{a}}$ & $33.36^{\mathrm{a}}$ & $31.21^{\mathrm{ab}}$ & 0.618 & 0.0002 & 0.0015 & 0.3780 \\
\hline Protein & $30.84^{\mathrm{b}}$ & $34.47^{\mathrm{a}}$ & $36.00^{\mathrm{a}}$ & $34.77^{\mathrm{a}}$ & 0.670 & $<0.0001$ & 0.0004 & 0.0135 \\
\hline Lactose & $34.19^{c}$ & $39.90^{\mathrm{b}}$ & $43.09^{a}$ & $39.95^{\mathrm{b}}$ & 0.784 & $<0.0001$ & $<0.0001$ & 0.0042 \\
\hline Ash & $5.56^{\mathrm{b}}$ & $6.30^{\mathrm{a}}$ & $6.36^{\mathrm{a}}$ & $6.19^{a}$ & 0.125 & 0.0001 & 0.0001 & 0.1079 \\
\hline \multicolumn{9}{|l|}{ Feed efficiency } \\
\hline Milk (milk/DMI) & 1.12 & 1.15 & 1.11 & 1.13 & 0.022 & 0.7137 & 0.4425 & 0.9440 \\
\hline Energy corrected milk (ECM; ECM/DMI) & 1.07 & 1.10 & 1.08 & 1.09 & 0.022 & 0.7544 & 0.2824 & 0.9718 \\
\hline
\end{tabular}

${ }^{*}$ Moringa oleifera added at 0\% (M0), 10\% (M10), 15\% (M15) and 20\% (M20), replacing 0\%, 50\%, 75\% and 100\% of sesame meal, respectively. ${ }^{a b c}$ Means in the same row with different superscripts significantly differ $(P<0.05)$.

$\mathrm{DMI}=$ Dry matter intake; SEM = Standard error of the mean 
Table 5

Fatty acids profile (g/100 g total fatty acids) in milk of lactating Anglo-Nubian goats fed on diets with different levels of Moringa oleifera replacing sesame meal as a protein source.

\begin{tabular}{|c|c|c|c|c|c|c|c|c|}
\hline & \multicolumn{4}{|l|}{ Diets ${ }^{*}$} & \multirow[t]{2}{*}{ SEM } & \multicolumn{3}{|l|}{$P$ value } \\
\hline & M0 & M10 & M15 & M20 & & Control vs. Moringa & Linear & Quadratic \\
\hline $\mathrm{C} 4: 0$ & 4.16 & 4.55 & 4.20 & 4.48 & 0.184 & 0.4105 & 0.1871 & 0.5815 \\
\hline C6:0 & 1.31 & 1.51 & 1.54 & 1.55 & 0.080 & 0.2122 & 0.1248 & 0.2009 \\
\hline $\mathrm{C} 8: 0$ & $2.71^{\mathrm{ab}}$ & $2.31^{\mathrm{b}}$ & $3.10^{\mathrm{a}}$ & $2.73^{\mathrm{ab}}$ & 0.135 & 0.0327 & 0.0788 & 0.2188 \\
\hline C10:0 & 6.27 & 5.72 & 6.17 & 6.41 & 0.324 & 0.5227 & 0.2799 & 0.3393 \\
\hline $\mathrm{C} 12: 0$ & 3.24 & 3.58 & 3.16 & 3.55 & 0.133 & 0.1521 & 0.1213 & 0.4241 \\
\hline C14:0 & 10.24 & 9.46 & 9.33 & 10.04 & 0.500 & 0.5473 & 0.3112 & 0.7655 \\
\hline C14:1 & $0.153^{b}$ & $0.198^{\mathrm{b}}$ & $0.598^{\mathrm{a}}$ & $0.488^{\mathrm{a}}$ & 0.0495 & 0.0017 & 0.5438 & 0.0021 \\
\hline $\mathrm{C} 15: 0$ & 1.29 & 1.33 & 1.37 & 1.34 & 0.034 & 0.4017 & 0.3565 & 0.4768 \\
\hline C16:0 & $28.12^{\mathrm{a}}$ & $26.54^{\mathrm{a}}$ & $22.03^{b}$ & $20.99^{b}$ & 0.721 & 0.0011 & 0.1727 & 0.0004 \\
\hline C16:1 & 1.18 & 1.27 & 1.54 & 1.50 & 0.162 & 0.3990 & 0.7234 & 0.2151 \\
\hline C17:0 & $1.185^{\mathrm{a}}$ & $0.873^{\mathrm{ab}}$ & $0.483^{b}$ & $0.700^{\mathrm{ab}}$ & 0.1271 & 0.0379 & 0.1328 & 0.0791 \\
\hline C18:0 & 12.50 & 11.66 & 11.39 & 12.63 & 0.631 & 0.4797 & 0.3829 & 0.5072 \\
\hline $\mathrm{C} 18: 1^{\mathrm{n} 9 \mathrm{~T}}$ & $23.52^{\mathrm{b}}$ & $27.08^{a}$ & $29.91^{\mathrm{a}}$ & $28.77^{\mathrm{a}}$ & 0.634 & 0.0017 & 0.0074 & 0.0043 \\
\hline $\mathrm{C} 18: 1^{\mathrm{n} 9 \mathrm{C}}$ & $2.13^{\mathrm{ab}}$ & $1.61^{b}$ & $2.72^{\mathrm{a}}$ & $2.46^{\mathrm{a}}$ & 0.126 & 0.0037 & 0.0259 & 0.0087 \\
\hline C18:2 trans-10, cis-12 & $0.548^{\mathrm{b}}$ & $0.858^{a}$ & $0.923^{a}$ & $0.908^{a}$ & 0.0316 & 0.0005 & 0.0004 & 0.0018 \\
\hline C18:2 $2^{\text {cis-9, trans-11 }}$ & $0.133^{b}$ & $0.145^{b}$ & $0.148^{\mathrm{ab}}$ & $0.163^{a}$ & 0.0031 & 0.0032 & 0.0308 & 0.0008 \\
\hline $\mathrm{C} 18: 3^{\mathrm{n} 3}$ & 0.130 & 0.163 & 0.175 & 0.143 & 0.0116 & 0.1180 & 0.0957 & 0.8013 \\
\hline$C 18: 3^{\text {n6 }}$ & 0.313 & 0.323 & 0.345 & 0.278 & 0.0315 & 0.5401 & 0.8299 & 0.3400 \\
\hline C20:0 & 0.888 & 0.850 & 0.873 & 0.898 & 0.0311 & 0.7325 & 0.4268 & 0.4792 \\
\hline TSFA & $71.89^{a}$ & $68.37^{\mathrm{ab}}$ & $63.65^{c}$ & $65.31^{\mathrm{bc}}$ & 0.746 & 0.0010 & 0.0157 & 0.0019 \\
\hline TUFA & $28.10^{c}$ & $31.64^{\mathrm{bc}}$ & $36.35^{a}$ & $34.70^{\mathrm{ab}}$ & 0.744 & 0.0010 & 0.0153 & 0.0018 \\
\hline MUFA & $26.98^{c}$ & $30.15^{b c}$ & $34.76^{a}$ & $33.21^{\mathrm{ab}}$ & 0.756 & 0.0014 & 0.0252 & 0.0024 \\
\hline PUFA & $1.12^{\mathrm{b}}$ & $1.49^{a}$ & $1.59^{\mathrm{a}}$ & $1.49^{a}$ & 0.058 & 0.0051 & 0.0042 & 0.0393 \\
\hline Total CLA & $0.68^{b}$ & $1.00^{\mathrm{a}}$ & $1.07^{\mathrm{a}}$ & $1.07^{\mathrm{a}}$ & 0.033 & 0.0004 & 0.0004 & 0.0012 \\
\hline$\omega-6 / \omega-3$ & 2.46 & 2.01 & 1.98 & 1.99 & 0.277 & 0.5859 & 0.2948 & 0.5067 \\
\hline TUFA/TSFA & $0.392^{c}$ & $0.463^{b c}$ & $0.572^{\mathrm{a}}$ & $0.532^{\mathrm{ab}}$ & 0.0173 & 0.0014 & 0.0264 & 0.0026 \\
\hline
\end{tabular}

${ }^{*}$ Moringa oleifera added at 0\% (M0), 10\% (M10), 15\% (M15) and 20\% (M20), replacing 0\%, 50\%, 75\% and 100\% of sesame meal, respectively.

${ }^{a b c}$ Means in the same row with different superscripts significantly differ $(P<0.05)$.

TSFA = total saturated fatty acids, TUFA = total unsaturated fatty acids, MUFA= mono unsaturated fatty acids, PUFA= poly unsaturated fatty acids, CLA= conjugated linoleic acid (C18:2 ${ }^{\text {trans }-10,}$ cis-12 and C18:2 ${ }^{\text {cis-9, }}$ trans-11) , SEM = Standard error of the mean.

protein flow to the small intestine of the host (Salem et al., 2013).

Soliva et al. (2005) studied the ruminal fermentation of M. oleifera leaves in comparison with soybean meal and rapeseed meal. They reported unaffected ruminal $\mathrm{pH}$ values and tVFA, and decreased ammonia-N concentration when $M$. oleifera leaves were degraded and fermented.

\subsection{Blood chemistry}

Decreased serum urea-N may be a result of decreased ruminal ammonia-N. Although GPT concentration was increased in the blood of goats fed MLM diets, the observed GOT and GPT concentrations were within the normal physiological range (Stanek et al., 1992).

The reduced blood cholesterol concentrations observed in MLM goats may be due to a functional effect of the phenolic acids in MLM. Saxena et al. (2013) stated that phytochemicals can reduce the synthesis and absorption of cholesterol. Moreover, reduced blood cholesterol and lipid levels are some of the biological activities of phenolic acids (Gryglewski et al., 1987). Astuti et al. (2011) reported that rations containing $M$. oleifera lowered serum cholesterol concentration. Khalel et al. (2014) found that blood glucose, total protein, albumin and globulin were higher for cows fed Moringa rations at 20 and 40\% than those fed on diet free of Moringa. However, blood cholesterol and urea were decreased with Moringa diets, with no effects on GOT and GPT.

\subsection{Milk yield and composition}

The major finding of the current study was that milk yield, and milk energy and nutrient outputs were markedly increased by replacing sesame meal with MLM in the goats' rations. Milk yield was increased by 10 to $15 \%$ when goats were fed MLM diets. The increased milk production is a result of the increased feed intake and enhanced nutrient digestibility and ruminal fermentation observed in goats fed MLM. Sarwatt et al. (2004) explained the increased milk production recorded in cows fed Moringa as a result of a positive effect on the rumen environment and fermentation, with an increased amount of microbial biomass and of feed undegraded protein reaching the abomasum. Khalel et al. (2014) also reported a significant increase in daily milk yield and improved milk composition in cows offered Moringa as a protein supplement.

In the current study, ruminal concentrations of propionic acid were increased in MLM fed goats. Propionate is the precursor for gluconeogenesis and lactose synthesis, and increased glucogenic precursors have a favourable effect on milk yield (Rigout et al., 2003). Although the content of milk lactose is fairly constant with small variations, in our study milk lactose content was significantly increased in goats fed MLM. Conversely, fat and protein concentrations in milk were not affected by including Moringa in the diets, probably because all diets, including control, provided adequate levels of fibre and protein (Huhtanen, 1994). However, Mendieta-Araica et al. (2011a) reported 
decreased milk yield without any effect in milk composition when soybean meal was replaced with MLM in the diets of dairy cows, as the protein and energy intakes were increased when cows were fed the soybean meal concentrate.

\subsection{Milk fatty acid profile}

Milk fatty acid profile was significantly affected by the inclusion of MLM in the diets of goats. Feeding MLM decreased TSFA in milk (up to $13 \%$ with M15 diet) and increased TUFA (up to 29\%, with M15 diet) and total CLA contents (up to $47-58 \%$ with MLM diets). The increased PUFA in total milk fatty acids observed with diets containing MLM is important for both human and animal health, as they are precursors of long chain $n-3$ PUFA that are considered as important bioregulators of many cellular processes and linked to the development and functionality of the immune system (Khotimchenko, 2005). Moyo et al. (2010) reported that Moringa is rich in PUFA, and its inclusion in the diet of ruminants is recommended as it prevents the occurrence of diseases and promotes good health. Moreover, MLM decreased the $\omega-6 / \omega-3$ ratio in milk, which is considered beneficial for the consumers. Human nutritionists urge consumers to increase intake of $n-3$ PUFA at the expense of $n-6$ PUFA.

The reason of the differences in milk fatty acids profile may be based on the distinct fatty acids profile in both MLM and sesame meal. Milk fatty acids originated mainly from plasma uptake ( $\sim 60 \%$ ) or by de novo synthesis in the mammary gland from acetate and 2-hydroxybutyrate derived from rumen fermentation, involving acetyl CoA carboxylase enzymes and fatty acid synthetase (Mesquita et al., 2008; Kholif et al., 2014). Ruminants do not synthesize PUFA; consequently their concentration in milk depends on the amount absorbed in the small intestine.

\section{Conclusion}

M. oleifera can replace sesame meal as a protein source in diets for lactating goats. The inclusion of Moringa leaf meal increases feed intake, enhances nutrient digestibility and ruminal fermentation and increases milk yield. Milk fatty acid profile is positively modified in goats fed Moringa leaf, as the relative percentage of unsaturated fatty acids and CLA are increased whereas saturated fatty acids are decreased. An inclusion rate of 15\% MLM (replacing 75\% of sesame meal) in the diet was the most suitable level for lactating goats under the current experiment conditions.

\section{Ethical approval}

All procedures performed in studies involving human participants were in accordance with the ethical standards and with the 1964 Helsinki declaration and its later amendments or comparable ethical standards.

\section{Conflict of interest}

All authors declare that there are no present or potential conflicts of interest among the authors and other people or organizations that could inappropriately bias their work.

\section{References}

Abdul, D.A.S., 2007. Economic Importance of Moringa oleifera in Tafa Local Government Area of Niger State. NDE Project. Federal College of Forestry Mechanization, Kaduna, Nigeria.

Alsersy, H., Salem, A.Z.M., Borhami, B.E., Olivares, J., Gado, H.M., Mariezcurrena, M.D., Yacuot, M.H., Kholif, A.E., El-Adawy, M., Hernandez, S.R., 2015. Effect of Mediterranean saltbush (Atriplex halimus) ensilaging with two developed enzyme cocktails on feed intake, nutrient digestibility and ruminal fermentation in sheep. Anim. Sci. J. 86, 51-58.

Annison, E.F., 1954. Some observations on volatile fatty acids in the sheep's rumen. Biochem. J. 57, 400-405.

AOAC, 1995. Official Methods of Analysis, 16th ed. Association of Official Analytical Chemists, Washington, DC, USA.

Astuti, D.A., Baba, A.S., Wibawan, I.W., 2011. Rumen fermentation, blood metabolites, and performance of sheep fed tropical browse plants. Media Peternakan 34, 201-206.

Becker, K., 1995. Studies on utilization of Moringa oleifera leaves as animal feed. Institute for Animal Production in the Tropics and Subtropics, vol. 480. University of Hohenheim, Stuttgart, pp. 15.

Brisibe, E.A., Umoren, U.E., Brisibe, F., Magalhaes, P.M., Ferreira, J.F.S Luthria, D., Wu, X., Prior, R.L., 2009. Nutritional characterization and antioxidant capacity of different tissues of Artemisia annua L. Food Chem. 115, 1240-1246.

Debela, E., Tolera, A., 2013. Nutritive value of botanical fractions of Moringa oleifera and Moringa stenopetala grown in the mid-Rift Valley of southern Ethiopia. Agroforest. Syst. 87, 1147-1155.

Duke, J.A., 2001. Moringa oleifera Lam. (Moringaceae). In: Duke, J.A. (Ed.), Handbook of Nuts. CRC Press, Boca Raton, FL, USA, pp. 214-217.

Fadiyimu, A.A., Alokan, J.A., Fajemisin, A.N., 2010. Digestibility, nitrogen balance and haematological profile of West African dwarf sheep fed dietary levels of Moringa oleifera as supplement to Panicum maximum. J. Am. Sci. 6, 634-643.

FASS, 1999. Guide for the Care and Use of Agricultural Animals in Agricultural Research and Teaching. Federation of Animal Science Society, Champaign, IL.

Ferret, A., Plaixats, J., Caja, G., Gasa, J., Prio, P., 1999. Using markers to estimate apparent dry matter digestibility, faecal output and dry matter intake in dairy ewes fed Italian ryegrass hay or alfalfa hay. Small Ruminant Res. 33, 145-152.

Foidl, N., Makkar, H.P.S., Becker, K., 2001. The potential of Moringa oleifera for agricultural and industrial uses. In: Proc. International Workshop What Development Potential for Moringa Products?, Dar-es-Salaam, Tanzania, pp. 47-67

Frutos, P., Hervás, G., Giráldez, F.J., Mantecón, A.R., 2004. Review. Tannins and ruminant nutrition. Span. J. Agric. Res. 2, 191-202.

Gryglewski, R.J., Korbut, R., Robak, J., 1987. On the mechanism of antithrombotic action of flavonoids. Biochem. Pharmacol. 36, 317-321.

Huhtanen, P., 1994. Forage influences on milk composition, forages. Seed to feed. In: Fredeen, A.H. (Ed.), Proc. NS Forage Council Conf. on Forages, Dartmouth NS. , pp. 144-162.

ISO-IDF, 2002. Milk Fat-preparation of Fatty Acid Methyl Esters. International Standard ISO 15884-IDF 182.

Khalel, M.S., Shwerab, A.M., Hassan, A.A., Yacout, M.H., El-Badawi, A.Y., Zaki, M.S., 2014. Nutritional evaluation of Moringa oleifera fodder in comparison with Trifolium alexandrinum (berseem) and impact of feeding on lactation performance of cows. Life Sci. J. 11, 1040-1054.

Kholif, A.E., Khattab, H.M., El-Shewy, A.A., Salem, A.Z.M., Kholif, A.M., El-Sayed, M.M., Gado, H.M., Mariezcurrena, M.D., 2014. Nutrient digestibility, ruminal fermentation activities, serum parameters and milk production and composition of lactating goats fed diets containing rice straw treated with Pleurotus ostreatus. Asian Australas. J. Anim. Sci. 27, 357-364.

Khotimchenko, S.V., 2005. Lipids from the marine alga Gracilaria verruscosa. Chem. Nat. Compd. 41, 285-288.

Lu, C.D., Kawas, J.R., Mahgoub, O.G., 2008. Review on recent advancement in fiber digestion and utilization in goats. Trop. Subtrop. Agroecosyst. 9, 65-72.

Makkar, H.P.S., 2003. Quantification of Tannins in Tree and Shrub Foliage. Kluwer Academic, Dordrecht, pp. 102-109. 
Meier, B., Julkunen-Tiitto, R., Tahvanainen, J., Sticher, O., 1988. Comparative high-performance liquid and gas-liquid chromatographic determination of phenolic glucosides in Salicaceae species. J. Chromatogr. 442, 175-186.

Mendieta-Araica, B., Spörndly, E., Reyes-Sánchez, N., Spörndly, R., 2011b. Feeding Moringa oleifera fresh or ensiled to dairy cows-effects on milk yield and milk flavor. Trop. Anim. Health Prod. 43, 1039-1047.

Mendieta-Araica, B., Spörndly, E., Reyes-Sánchez, N., Salmerón-Miranda, F., Halling, M., 2013. Biomass production and chemical composition of Moringa oleifera under different planting densities and levels of nitrogen fertilization. Agroforest. Syst. 87, 81-92.

Mendieta-Araica, B., Spörndly, R., Reyes-Sánchez, N., Spörndly, E., 2011a. Moringa (Moringa oleifera) leaf meal as a source of protein in locally produced concentrates for dairy cows fed low protein diets in tropical areas. Livest. Sci. 137, 10-17.

Mesquita, I.V.U., Costa, R.G., Queiroga, R.R., de Medeiros, A.N., Schuler, A.R.P., 2008. Profile of milk fatty acids from Moxotó goats fed with different levels of manicoba (Manihot GlazioviiMuel Arg) silage. Braz. Arch. Biol. Technol. 51, 1163-1169.

M'hamed, D., Faverdin, P., Verité, R., 2001. Effects of the level and source of dietary protein on intake and milk yield in dairy cows. Anim. Res. 50, 205-211

Moyo, B., Masika, P.J., Hugo, A., Muchenje, V., 2010. Nutritional characterization of Moringa (Moringa oleifera Lam.) leaves. Afr. J. Biotechnol. 10, 12925-12933

Nouman, W., Basra, S.M.A., Siddiqui, M.T., Yasmeen, A., Gull, T., Alcayde, M.A.C., 2014. Potential of Moringa oleifera L. as livestock fodder crop: a review. Turk. J. Agric. For. 38, 1-14.

NRC, 2001. Nutrient Requirements of Dairy Cattle, 7th revised ed. National Academy Press, Washington, DC, USA.

NRC, 2007. Nutrient Requirements of Small Ruminants: Sheep, Goats, Cervids and New World Camelids. National Academy Press, Washington, DC, USA.

Ørskov, E.R., Ryle, R., 1990. Energy Nutrition in Ruminants. Elsevier Science Publishers, New York

Palada, M.C., Chang, L.C., Yang, R.Y., Engle, L.M., 2007. Introduction and varietal screening of drumstick tree (Moringa spp.) for horticultural traits and adaptation in Taiwan. Acta Hort. 752, 249-253.

Patel, J.P., Bharat, G., Patel, K., 2010. Evaluation of in vitro schizonticidal properties of acetone extract of some Indian medicinal plants. Adv. Biol. Res. 4, 253-258.

Reyes-Sánchez, N., Spörndly, E., Ledin, I., 2006. Effect of feeding different levels of foliage of Moringa oleifera to creole dairy cows on intake, digestibility, milk production and composition. Livest. Sci. 101, 24-31.

Rigout, S., Hurtaud, C., Lemosquet, S., Bach, A., Rulquin, H., 2003. Lactational effect of propionic acid and duodenal glucose in cows. J. Dairy Sci. 86, 243-253.

Safwat, M.A., Sarmiento-Franco, L., Santos- Ricalde, R.H., 2014. Rabbit production using local resources as feedstuffs in the tropics. Trop. Subtrop. Agroecosyst. 17, 161-171.
Salem, A.Z.M., Alsersy, H., Camacho, L.M., El-Adawy, M.M., Elghandour, M.M.Y., Kholif, A.E., Rivero, N., Alonso-Fresán, M.U., Zaragoza, A., 2015. Feed intake, nutrient digestibility, nitrogen utilization and ruminal fermentation activities of sheep fed Atriplex halimus ensiled with developed enzyme cocktails. Czech J. Anim. Sci. 60, 185-194.

Salem, A.Z.M., López, S., Ranilla, M.J., González, J.S., 2013. Short to mediumterm effects of consumption of quebracho tannins on total and parotid saliva production and composition in sheep and goats. J. Anim. Sci. 91, $1341-1349$.

Salem, A.Z.M., Salem, M.Z.M., El-Adawy, M.M., Robinson, P.H., 2006. Nutritive evaluations of some browse tree foliages during the dry season: Secondary compounds, feed intake and in vivo digestibility in sheep and goats. Anim. Feed Sci. Technol. 127, 251-267.

Sánchez-Machado, D., Núñez-Gastélum, J., Reyes-Moreno, C., RamírezWong, B., López-Cervantes, J., 2010. Nutritional quality of edible parts of Moringa oleifera. Food Anal. Method 3, 175-180.

Sarwatt, S.V., Milang'ha, M.S., Lekule, F.P., Madalla, N., 2004. Moringa oleifera and cottonseed cake as supplements for smallholder dairy cows fed Napier grass. Livest. Res. Rural Dev. 16, Art \#38. Accessed February 24, 115, from http://www.lrrd.org/lrrd16/6/sarw16038.htm

SAS, 2004. Statistical Analysis Systems, Version 9.2. SAS Institute, Cary, NC.

Satter, L.D., Slyter, L.L., 1974. Effect of ammonia concentration on rumen microbial protein production in vitro. Br. J. Nutr. 32, 199-208.

Saxena, M., Saxena, J., Nema, R., Singh, D., Gupta, A., 2013. Phytochemistry of medicinal plants. J. Pharmacogn. Phytochem. 1, 168-182.

Sjaunja, L.O., Baevre, L., Junkkarinen, L., Pedersen, J., Setala, J., 1991. A Nordic Proposal for an Energy Corrected Milk (ECM) Formula. Performance Recording of Animals. State of the Art, vol. 50. EAAP Publication, pp. $156-157$

Soliva, C.R., Kreuzer, M., Foidl, N., Foidl, G., Machmüller, A., Hess, H.D., 2005. Feeding value of whole and extracted Moringa oleifera leaves for ruminants and their effects on ruminal fermentation in vitro. Anim. Feed Sci. Technol. 118, 47-62.

Stanek, M., Florek, S., Rydzik, W., Rusiecka, I., 1992. Effect of energy feeds in diets for sheep on nutrient digestibility and rumen digestion process. Acta Acad. Agric. Tech. Olstenesis Zootech. 37, 3-11.

Sultana, N., Alimon, A.R., Huque, K.S., Sazili, A.Q., Yaakub, H., Hossain, J., Baba, M., 2015. The feeding value of Moringa (Moringa oleifera) foliage as replacement to conventional concentrate diet in Bengal goats. Adv. Anim. Vet. Sci. 3, 164-173.

Tyrell, H.F., Reid, J.T., 1965. Prediction of the energy value of cows milk. J. Dairy Sci. 48, 1215-1223.

Van Soest, P.J., Robertson, J.B., Lewis, B.A., 1991. Methods for dietary fiber, neutral detergent fiber, and non-starch polysaccharides in relation to animal nutrition. J. Dairy Sci. 74, 3583-3597.

Varel, V.H., Jung, H.G., Krumholz, L.R., 1991. Degradation of cellulose and forage fiber fractions by ruminal cellulolytic bacteria alone and in coculture with phenolic monomer-degrading bacteria. J. Anim. Sci. 69, 4993-5000. 